\title{
CYPRUS, AN UNRESOLVED ISSUE OF THE EUROPEAN UNION
}

\author{
Ileana-Gentilia METEA \\ "Nicolae Bălcescu" Land Forces Academy, Sibiu, Romania \\ meteaileana@yahoo.de
}

\begin{abstract}
The Republic of Cyprus is an island from the extreme north of the Mediterranean Sea, is situated at the intersection of Europe, Asia and Africa, $75 \mathrm{~km}$ south of Turkey, $105 \mathrm{~km}$ west of Syria, $300 \mathrm{~km}$ north of Egypt and $800 \mathrm{~km}$ east of Greece. As a state form, it is a presidential republic, and is part of the European Union (since May 2004) the Euro Zone (2008), the World Trade Organization WTO (1995), the International Monetary Fund (1962) 1962), the Council of Europe (1961), the Commonwealth (1961). Cyprus has an unresolved internal situation for a long time.
\end{abstract}

Keywords: violence-free conflict, british colony, independence, negotiation, war

\section{Introduction}

I have chosen Cyprus because it represents a problem matter within the European Union, an outbreak of negative tensions in the region.

I mention that we are dealing with a conflict, a frozen conflict and a current one, precisely because of Cyprus's membership of the European Union. On the island, the population has been separated since 1974, with the military forces of the Republic of Turkey stationing here, in the Republic of Northern Cyprus, an entity recognized only by Turkey. The situation can be described as a violence-free conflict arising from an agreement or a ceasefire treaty. Characteristic of these conflicts is that despite the fact that the violence has ended, the situation is not the same with the conflict-generating problem, this being only partially solved, the mistrust and initial claims remaining valid in that area. For example, there may be more frozen conflicts related to the Yugoslav space, but more prominent are those in the former Soviet space: the Nagorno-Karabakh conflict between Armenia and Azerbaijan, the Transnistrian conflict, or the conflicts in
Abkhazia and South Ossetia. It is demonstrated that certain so-called frozen conflicts can degenerate, in some contexts, into violence, the situation in 2008 with Russia intervening in South Ossetia on Georgian territory being eloquent. Trying to give a detailed description of the conflict situation in Cyprus, there are several factors that have agravated the divergences among the Cypriot population, then degenerate into violence and ultimately produced splitting.

\section{History and evolution over time}

Former British colony, until 1960, the population of the island is mostly Greek, and there is also a Turkish minority. Over the time, the two communities identified themselves with their own countries, Greece as a result of its independence in the nineteenth century and Turkey after the establishment of the republic by Mustafa Kemal Ataturk in the 1920s.

\subsection{From British domination to independence}

During the British domination, the church was the main decident of both political and social life. This has led to more pronounced differences between the two communities. 
The Greek Cypriots followed their own national struggle, which they called "enosis", meaning union, union with Greece. The refusal of the British Empire to surrender any territory was categorical, with Greece adopting a reserved position. The population, especially the youth, embraces this idea of uniting with Greece. Except for some situations, there have been no clashes between the two communities either during the interwar period or during the retreat. Colonial laws have been tightened since 1931 following the Cypriot revolt against the British rulers, with consequences on education and organization. The war period brings as a novelty, to the development of two political directions, one of the left, communist, called AKEL, and the other of the right, of the bourgeoisie and the church, under the name of the Cypriot National Party. Despite the "thaw" of the colonial laws, after 1945, the UK rejects the right to self-determination and, automatically, the union with Greece. Negotiations are followed by failure. The offer of the British was to offer the possibility of selfgovernment, which was rejected by the right-wing group, insisting on enosis, by contrast with the Turkish Cypriots who declared themselves open to the offer.

In 1950, the Bishop Makarios III became the youngest archbishop of Cyprus. At international level, he was noted as the leader of the liberation movement. From a geostrategic point of view, the situation of Cyprus' independence or union with Greece must be seen in the 1950s as the moment of the birth of pan-Arabism, the Arab-Israeli conflict, the Suez crisis and the consolidation of the states of the Middle East. The island became important from a strategic perspective for the UK following the takeover of power by Abdel Gamal Nasser, the Suez crisis as a consequence of the deplayment of the British headquarters from Cyprus to Egypt.

The Cold War and the finalization of the two military blocks have also set footprints over the 1950s. This leads to the situation in which Cyprus has the greatest importance within the North Atlantic Alliance. For the West, a Cyprus led by a government lacking stability, whether it was Greece, whether it was an independent one, was a problem. Makarios changed the strategy in 1955. The EOKA-National Organization of Cypriot Fighters is set up. Over time, the organization finds followers among young people. It is the time for the British to intervene and, according to the strategy, "divide and reign", instigated Turkish Cypriots to fight against EOKA, thus causing hatred among the ethnicities. The Turkish Cypriot organization is under the command of some Turkish army officers, called TMT-FFour Turkish Defense. Their actions are under British protection. At that time, a conference is organized by the British, attended by representatives of Greece and Turkey. The goal pursued by the British was to involve the Turks in the conflict. The British organize a conference in the same year where guests from Turkey and Greece are invited. The objective of the British was to introduce Turkey as an interested party to the conflict. Thus, over time, Greece and Turkey will come to dispute the territory of the island of Cyprus.

\subsection{Independent state under Makarios}

The independence of the Cypriot state was decided in 1958 by the Greek Prime Minister and the Turkish under the Zurich and London Agreements and the Republic of Cyprus proclaimed. Controlled from three directions, the United Kingdom, Greece and Turkey, the new independence will be limited. A treaty that gives the three signatory powers a chance to intervene in the event of a constitutional amendment will be ratified. Turkey will use this right in 1974 when it invades the island. De facto, the independence of Cyprus begins on August 16, 1960, with Makarios as the first president of the Republic of Cyprus. He is supportive of the idea that Cyprus should participate in the non-alignment movement. The reason for the discord in the ethnic conflict was represented by the constitution, 
more precisely the inappropriate representation of the structure of society, but the influence of the communities involved, namely the Turks had a $30 \%$ representation in political life, despite the fact that they represented only 18 percent of the population on the island. In addition, the citizens of the island, be they Greek or Turkish, were not citizens of the Cypriot constituency, but members of the communities they were part of. Thus constitutional rights were conferred upon them.

The constitution did not favor the state, accentuating the differences and favoring the emergence of radical movements. Between the two communities a separation generated by violence has been created. We are witnessing the splitting of Nicosia and the claiming of a separate area by the Turkish Cypriots. These conflicts were the basis for the 1963 rise of the government crisis. Turkish Cypriots holding government portfolios have resigned, forming a general committee only for their community, having legislative and executive power and being led by Vice-President Kuchuk. In 1967, the government is represented only by the Greek Cypriots, the Temporary Committee representing the Turkish-Cypriot administration. The intervention of the United Nations is the only one accepted by Makarios. In an attempt to avoid the repositioning of Cyprus at the confluence of foreign interests, he accuses the United Kingdom, Turkey, Greece and NATO of the problems that have arisen between the two communities. In March 1964 UNFICYP is being established in Cyprus, a peacemaking operation that has been ongoing so far. Economic differences led to the political separation of the two communities. Tourism, the main activity of the Greek Cypriots, leads to economic growth between 1964 and 1974, thus leading to an increase of the living standards. The economic differences will be the argument brought to the negotiation table for EU membership, that the Turkish Cypriots have been deprived of this development. The tension between Greece and Turkey takes on concrete forms. In the absence of a well-structured military structure of Cyprus, the Greeks are sending troops to the island. In response, Turkey threatens to invade the island. Due to international involvement, the threat will only materialize in 1974. Following the 1967 state strike and the rebuilding of the military junta, Greece is changing its policy towards Cyprus. Supported by the United States, the right wing installed in Greece organizes a series of attacks against Makarios. Greece aims at removing Makarios, from power associated with Cyprus's independence, and annexing it.

Greece's military junction organizes a coup in 1974, Makarios flees from Cyprus, the situation being created, according to the guarantee agreement, the example of a situation where one of the guarantors could intervene. Five days later, Turkey invades Cyprus. The military junta of Greece falls on July 24, after 7 years of dictatorship, forming a new government. In the immediate aftermath, negotiations took place, based on the 1960 Constitution, aiming at resolving the problems in Cyprus, negotiations interrupted on 14 August by a new Turkish offensive. This is followed by the $37 \%$ occupation of the Cypriot territory by the Turkish army. Both the city of Nicosia and the island between North and South are delineated by the so-called Atilla line. The battles ended with 200,000 refugees and 4,000 dead. Out of Turkey's initiative is made an exchange of population, so Turkish Cypriots are brought north of the Attila line. Makarios dies in the late 1970s, and with his disappearance the period of church involvement in political life ends. Negotiations that have afterwards taken place have not given any results.

\subsection{The Cypriot state after Makarios}

In 1983, the northern part of the island declared the founding of the Turkish Republic of Northern Cyprus. This act is the equivalent of a unilateral declaration of independence. The new state has not been 
officially recognized by any other state except Turkey. By exchanging embassies, the two countries begin diplomatic relations. Denkas, the leader of Turkish Cypriots and Turkey, brought settlers from Turkey as part of a demographic change operation, denounced by both the Greek Cypriots and the UN. Due to the intransigence of the Turkish Cypriots, the plans to resolve the Cyprus problem have not found any solution.

2.4. The period of accession to the European Union

A joint defense program was created in the 1990s by the Greek Cypriots together with Greece. Cyprus' accession to the European Union is not jeopardized by the unresolved issue of the Cypriots. By 2004, there have been several attempts to resolve it, the most significant being the "Annan Plan" proposed by UN Secretary General Kofi Annan. The plan issued the formation of a federation comprising the two Cypriot states following the Swiss model. In 2004, the plan is subject to a referendum, being accepted by $65 \%$ of the Turkish Cypriots and rejected by $76 \%$ of Greek Cypriots. Despite the unresolved issues, Cyprus becomes a member of the European Union on May 1st. The government of the Cypriot Greeks is internationally recognized, joining the European Union, resulting in the Cypriot Greeks obtaining diplomatic influence on the Turkish Cypriots and Turkey, since the acceptance of Turkey's EU bid requires the agreement of all member countries. Cyprus remains a problem issue on the world's geopolitical map, a frozen conflict, the factors that led to the freeze of the conflict being multiple, both external and internal. The guarantor powers, the US, the EU and the UN, are the external factors. The 1960 Constitution did not favor a united Cypriot state, but rather the separation between communities. The United Nations is not responding to the outbreak of the crisis in 1974, although the United Kingdom, although holding the legal basis of the guarantee treaty, intervenes late.
For the US, whose politics was influenced by its own geopolitical interest adapted to the times, Turkey was much more important than Cyprus, as a precious ally during the Cold War and a major member of NATO.

In his statement, US Secretary of State Henry Kissinger claimed that there was no American interest that Turkey should not have occupied a third of the island's territory [1].

UNO weaknesses, materialized by the impossibility of preventing violence and the humanitarian disaster from 1974, have been highlighted by the presence of UNFICYP before and after the invasion of 1974, this maintaining the border between the two communities. In 1990, the resolution of the Cyprus problem was not considered by the EU to be an essential one for granting membership. The Annan Plan is rejected in 2004 by the Cypriot Greeks and accepted by the Turkish Cypriots. Consequently, only Cyprus led by the Greek Cypriots becomes a member of the European Union. As internal factors, we consider the lack of Cypriot national sentiment, the two communities being identified with mother countries, the presence and acceptance of internal borders, population exchanges since 1974, and especially the intransigence of both groups over time.

\section{Cyprus relations in the current geopolitical context}

Cyprus has begun to look for oil offshorns with Israel's findings in the Mediterranean about the existence of two major oil reserves. Turkey has threatened Cyprus with such actions, with Minister Ahmet Davutoglu saying his country will give the "necessary response" if Cyprus dares to go ahead. Cyprus and Turkey are stuck in a dispute over the property of Turkey's northern region, the Ankara government pretending to belong to the region, threatening repeatedly with military action.

\subsection{Israeli assistance in the Cypriot issue}

Since the start of the conflict, both the US and Russia have supported Cyprus' position, 
supporting international law. Cypriot Foreign Minister Erato Kozakou-Marcoullis paid a visit to Israel seeking support from the Israeli government. The request was received and both Foreign Minister Avigdor Lieberman and Prime Minister Benjamin Netanyahu took official stance on Cyprus, encouraging his country to continue with oil. Cyprus's decision to ask for help to Israel was surprising, given that the country's position on Israel at the UN was extremely critical in the past. Many speculated that the move is linked to the deterioration of the Israel-Turkey relationship since the 2010 flotilla incident. Both Israel and Cyprus have rejected such rumors, saying it is linked to Cyprus's entry into the EU in 2004, and Israel's desire for to have economic links with the EU [2].

\subsection{Conflicts of power in the Eastern Mediterranean}

The Eastern Mediterranean has entered a worrying period. It is the most uncertain and conflictual strategic context since the crisis around the Imia rocky islands from 1996 when Greece and Turkey were very close to engaging in an armed conflict for sovereignty over these rocky islands, but the sources of risk are today deeper and wider than in the previous decades. Greece, Turkey and Cyprus have benefited from a normalization of the relations that have been in the region since the late 1990s. These benefits have been widely felt in Europe and on the other side of the Atlantic. The EU and NATO have afforded the luxury of no longer worrying about traditional conflict points such as the Aegean, Cyprus, Baltic and Thrace maritime and air space. Political leadership in the region and on the two shores of the Atlantic do not allow the luxury of being quiet. The dangers of risky diplomacy and of an accident have reaccured. First of all, none of the political and territorial differences has been resolved. This in itself is not a direct danger, but it becomes more problematic in connection with the growing naval and air activity in the Aegean Sea, but also with attempts to commercially exploit the region's energy resources.

\subsection{Common interest for resources in the Eastern Mediterranean}

Greece, Turkey, Cyprus, Israel and Egypt have a common interest in getting as much resources as possible in the Eastern Mediterranean, including in energy and tourism. The dominant tension in the region makes it difficult to develop and capitalize on these resources; in particular, in the field of the exploitation of energy resources in the maritime space where the cost of submarine pipelines is very high, and regional cooperation is of vital importance. It is also the "key" to minimize environmental risks. In the face of a geopolitical confrontation, the use of energy resources is questioned. Secondly, the tense atmosphere on both sides of the Aegean Sea makes it difficult to moderate diplomacy. Under normal circumstances, the case of Greek militaries who crossed the Greek-Turkish border by mistake would have been resolved immediately and tacitly. From the Balkans to the Near East, governments fear more than anything to be weak. Nationalism is a strong force in the region, especially in Turkey, which faces numerous security challenges [3].

\section{Conclusions}

The Republic of Cyprus, founded in 1960, after four years of struggle against Great Britain, for national liberation under the colonial power of the island was for the first time since antiquity when the Cypriots themselves were in the position to become the masters of their own destiny. Cyprus, which is at the intersection of three continents - Europe, Asia and Africa - has been a source of dispute for centuries for the regional powers who wanted to control it and have disputed the Eastern Mediterranean region.

The history of Cyprus is one of the oldest in the world, with the first signs of civilization, documented by archaeological excavations, dating back almost 11,000 years, from the 9th millennium BC After the Hellenization 
of the island 3,000 years ago, there was an ongoing attempt to dominate the country by the various Eastern Mediterranean regional powers: Romans, Persians, Assyrians, Arabs, Byzantines, Venetians, Crusaders, Ottomans, and finally, by the British Empire, all leaving its mark, which is now reflected in the rich cultural heritage of Cyprus.

The independence of Cyprus has come up with a dysfunction, with a constitution imposed, reflecting the much-tested policy of "colonizing and ruling" the colonial power that sowed the seed of the division between the Greek Cypriots, representing $80 \%$ of the population and the Turkish Cypriots, which is $18 \%$. Three years after its inception, in 1963, the first signs appeared that something had not worked properly. This culminated in the overthrow of the legitimate government by the military junta that governed Greece in 1974, and after five days the Turkish military invasion and the subsequent occupation of $37 \%$ of its territory followed the forced expulsion of 200,000 Greek Cypriots from the homes and their possessions. Since then, the island is divided. Efforts to achieve a global solution for reunification are under way and a new round of negotiations is on its way under the mandate of the UN Secretary-General.

Despite the negative impact of the political issue, Cyprus has shown a remarkable adaptability since the founding of the Republic, reaching particularly high rates of development over the 55 years of independence and providing the people with a high standard of living, in a democratic country, with full respect for human and political rights. This led to Cyprus' accession to the European Union in 2004 as a clear contributor, despite the fact that the island remained divided. In 2012, the country took over the presidency of the European Council, succeeding in a successful Union presidency. The global economic crisis, which began in 2008 and hit hard, especially the southern part of Europe, has deeply affected the island. In 2013, Cyprus has had to seek financial support from its creditors, the European Union, the European Central Bank and the International Monetary Fund. The Government of Cyprus has implemented a package of measures contributing to the recession of Cyprus by implementing the necessary reforms.

Cyprus, a small island country, situated in an unstable region of the planet, aims to become a pillar of stability in the region, continuing its policy of promoting peace, colaboration and cooperation with all its neighbors, including Turkey. The recent discovery of significant natural gas resources in the exclusive economic zone of Cyprus, the prospect of several such discoveries, the slow but constant recovery of the economy and the desire of the Greek and Turkish Cypriots to reunify the country, as expressed in the election of their two leaders who are devoted to solving the Cyprus problem, offer hope for a better future. There are strong friendships between Cyprus and Romania. Cyprus is the sixth largest investor in the Romanian economy, and the existence of a strong Romanian community in Cyprus is a guarantee that our relations will continue to grow. As partners in the European Union, Cyprus and Romania have a strong tradition of mutual friendship and trust, common interests and visions, working together to solve contemporary problems. Cyprus has firmly supported Romania's integration into the European Union and is now supporting the adherence of the friendly country to the Schengen area".

\section{References}

[1] Cipru-un-conflict-inghetat pe:https://lanivelglobal.wordpress.com/2013/08/10/ /.

[2] Băiaș, Ion, Grecia, Cipru, Turcia şi ameninţarea izbucnirii unui conflict pe: $\mathrm{http}: / / w w w . c u v a n t u l-o r t o d o x . r o / r e c o m a n d a r i / c$

[3] Grecia-cipru-turcia-amenintarea-izbucnirii-unui-conflict pe:https://www.hotnews.ro/stiriinternational-22397559- 